\title{
Application of Data Envelopment Analysis to Evaluate Investments in the Modernization of Collective Management Irrigation Systems in Valencia (Spain)
}

\author{
Marta García-Mollá ${ }^{1} \cdot$ Rosa Puertas $^{2} \cdot$ Carles Sanchis-Ibor $^{1}$
}

Received: 24 June 2021 / Accepted: 23 September 2021 /Published online: 1 October 2021

(c) The Author(s) 2021

\begin{abstract}
Climate change and increased competition for water resources are generating growing concern about how to improve water-use efficiency in agriculture. In turn, this has prompted substantial investments in the installation of water-saving technologies in irrigation systems. The first aim of this research is to use data envelopment analysis to quantify, in terms of gross water savings (GWS), the local-scale efficiency of the irrigation policies adopted in an area of Spain suffering from a structural water deficit. Second, the cross-efficiency method is used to produce a ranking of the irrigation organizations analysed, in order to identify patterns of water-use efficiency performance that can guide future lines of investment. The results reveal that water-use efficiency prior to modernization is a key determinant of the efficiency achieved in terms of GWS at local scale. However, the investments targeted at irrigation modernization often have objectives other than water savings. These and other aspects should be taken into account when allocating public funds to irrigation modernization.
\end{abstract}

Keywords Collective irrigation management - Data envelopment analysis · Drip irrigation · Gross water savings · Irrigation policy

\section{Introduction}

The efficient use of water has become a challenge of global dimensions. One of the targets set by the United Nations (2020) in the Sustainable Development Goals (SDGs) is to achieve a substantial increase in water-use efficiency across all sectors. The agricultural

Marta García-Mollá

mgarmo@esp.upv.es

Rosa Puertas

rpuertas@esp.upv.es

Carles Sanchis-Ibor

csanchis@hma.upv.es

1 Centro Valenciano de Estudios del Riego, Universitat Politècnica de València, Camí de Vera s/n, 46022 València, Spain

2 Economics and Social Sciences Department (Building 7J), Universitat Politècnica de València, Camí de Vera s/n, 46022 València, Spain 
sector is the largest consumer of fresh water, accounting for $70 \%$ of all withdrawals from water bodies, and as much as $90 \%$ in developing countries (FAO 2017). As such, there is a critical need to develop irrigation techniques and management practices that ensure the efficient use of water.

Water-use efficiency in irrigation has been analysed using different techniques and from various perspectives (Pereira and Marques 2017; Nazari et al. 2018; Yu et al. 2020). Indeed, the concept of efficient water use means different things to researchers in different disciplines (Nair et al. 2013). Most of the related literature focuses on specific agricultural products, identifying the actions needed to maintain the same level of profitability while reducing water use, either through case studies or comparative studies (Imran et al. 2019; Wang et al. 2019; Volschenk 2020; Wang et al. 2020; Narayanamoorthy et al. 2020; Cao et al. 2021). Based on this scientific research, international institutions have called for modernization and improved efficiency, which has influenced national irrigation plans worldwide (De los Reyes and Schultz 2018; Khadra and Sagardoy 2019; Molle et al. 2019; World Bank 2019).

Drip irrigation (DI) is widely used in many regions of the world, because of its proven capacity to reduce water withdrawals at the level of the irrigation system or plot (Tsakmakis et al. 2018; Bai et al. 2020). However, the supposed efficiency of DI has recently been contested on various grounds (Venot et al. 2017; Grafton et al. 2018), mainly because water saved at local scale is frequently lost at basin level (Berbel et al. 2015; Perry and Steduto 2017). Furthermore, the pursuit of efficiency may justify policies and plans that deprive smallholders of water-use rights and erase valuable cultural practices (Boelens et al. 2018). For these reasons, we need a better understanding of several aspects of wateruse efficiency: first, how new irrigation technologies generate gross water savings (GWS) at the local level; second, whether the policies to promote these tools are efficient; and third, whether these water savings are converted into net savings or are lost at higher scales.

This paper attempts to shed light on the first two of these questions. The evaluation of efficiency at the local scale can be estimated by constructing a production function that transforms certain inputs into outputs; to that end, data envelopment analysis (DEA) is applied in this study. This linear programming method is used to measure the productive efficiency of homogeneous decision-making units (DMUs) based on the characteristic inputs/outputs of each DMU. Depending on whether an input- or output-oriented model is used, DEA determines the extent to which the inputs could be reduced while maintaining the same output levels, or vice versa (Charnes et al. 1978). The scientific literature includes numerous studies that demonstrate its capacity for measuring efficiency in different spheres, such as financial performance (Sukmana et al. 2020; Hafsal et al. 2020), industrial production (Guo et al. 2020; Rezaee et al. 2020), agrarian production (Li et al. 2018; Bagchi et al. 2019), and even services (Yin et al. 2020; Cinaroglu 2021).

In recent decades, irrigation organizations in regions with scarce water resources have invested heavily in the installation of new irrigation technologies to reduce water use. There are many studies that use DEA to evaluate irrigation efficiency, most of which take agricultural production variables as the output (Pereira and Marques 2017). However, few studies using this method focus on the efficiency of water-saving techniques. The main novelty of this study is that the results are calculated in terms of GWS at the level of the water users' association (WUA). The aim is to measure the efficiency improvements achieved through DI, based on the assumption that these improvements may be influenced by the type of WUA. For this purpose, DEA is used to (1) determine through two production functions the extent to which investments should be targeted at the implementation of DI in order to maximize GWS and (2) quantify the changes in the analysed variables (investment, water 
use, DI, GWS ) needed to achieve the maximum efficiency in their use; and (3) establish a ranking of the irrigation organizations' efficiency, using cross efficiency (CE).

Efficient water management in agriculture has been extensively analysed in recent research, with the results of those studies driving progress by identifying the most appropriate policies for each situation (Wang et al. 2018; Bagchi et al. 2019; Berbel et al. 2019; Geng 2020; Martinho 2020). The empirical analysis carried out in this research yields new findings that can better guide the actions of irrigators and policy-makers. In this regard, it makes a threefold contribution: (1) by using two models, it covers a broader spectrum of the GWS paradigm, (2) it provides evidence on the improvement needed in the inputs/ outputs to reach the maximum level of efficiency, and (3) by establishing a ranking of the irrigation organizations, it sheds light on the irrigator profiles that make the best use of their resources.

\section{Methodology and Data Sources}

In this study, output-oriented DEA is used to assess whether the investments made, the use of water, or the surface area over which DI is applied by irrigation organizations in the Region of Valencia (CV by its initials in Spanish) have had the effect of maximizing GWS. The database used was compiled through an individual survey administered to those in charge of these organizations before and after implementing DI. In the pre-modernization situation, many organizations did not have objective methods for monitoring water inputs; the volume of water was estimated on the basis of the theoretical flow and irrigation time. This is a limitation of the study because the imprecision of some of the answers given meant that a significant number of observations had to be excluded, reducing the sample to 28 irrigation organizations. However, this number is considered large enough to constitute a representative selection of the diverse entities in the CV. Moreover, DEA can be used with small sample sizes and does not require additional observations to validate the efficacy of the proposed model. Another limitation is that it has not been possible to identify the investments that were specifically targeted at GWS, hence two different scenarios have been considered: the efficiency of all investments made (model 1) and DI efficiency (model 2).

\subsection{Case Study}

The study area encompasses the irrigated lands of the CV on the eastern coast of Spain. The region is host to a varied array of irrigation landscapes (336,000 ha) supplied with groundwater $(32 \%)$, surface water $(60 \%)$, and nonconventional resources (7\%). Rainfall ranges from 300 to $650 \mathrm{~mm}$ and evapotranspiration from 25 to $60 \mathrm{~cm}$. Citriculture predominates $(180,000$ ha) among a diverse Mediterranean crop pattern (GVA 2020). The typical farm structure is a smallholding (mean farm size is $5.5 \mathrm{ha}$ ), over $40 \%$ of the area is managed by part-time farmers, and farmers are aging (mean age is 64.5) (INE 2011). The vast majority of the irrigation systems are collectively managed through a WUA.

In this region, the growth in the demand for water has given rise to a structural water deficit. In recent decades, both public administrations and irrigation organizations have made major investments in the modernization of the infrastructure. This reform, which focused on the installation of DI (predominantly surface drip irrigation systems), dates back to the severe 
drought in 1994-1995, and came about thanks to joint decisions made by the administration and the WUAs (Sanchis-Ibor et al. 2016). In the four-year period 1996-2000 alone, 434 works were financed in different organizations of the region. This was followed by a further 431 , until the 2008 financial crisis slowed down the investments of the regional government, and paralysed them entirely during the period 2012-2015. As a result of this process, there has been an unprecedented technological change in Valencian irrigation: in 1992, DI was used on $13.5 \%$ of the irrigated area, with this figure rising to $72 \%$ by 2019 (MAPA 2020). That said, the source of the funds allocated to DI-variously coming from the national or regional governments or the European Union-has led to important differences in the investments made in the CV and their ultimate purpose (García-Mollá et al. 2017).

Farmers and WUAs value not only the GWS associated with the modernization of irrigation systems, but also other advantages such as the convenience, which improves the quality of life of an aging sector of the population (Sanchis-Ibor et al. 2016), or the reduction in fertilization costs (Poblador et al. 2021). The modernization policies carried out in the CV have been successful in terms of GWS: water use has been reduced by almost half through the application of DI (García-Mollá et al. 2017). However, there are important differences between irrigation organizations, due not only to the amount of funds invested but also to other practices that influence water use, such as pressurized irrigation. As such, there is a need to empirically quantify the efficiency of the measures taken.

\subsection{Data Envelopment Analysis Model}

DEA is a non-parametric method that allows an efficient frontier to be constructed from the available observations. It is based on the use of linear programming to determine the distance of each DMU from the frontier formed by the efficient units. The sample used must be fairly homogenous since the approach involves measuring the efficiency of each DMU in relation to the best positioned ones, meaning that outliers could distort the results (Golany and Roll 1989). DEA was originally used to evaluate the relative efficiency of non-profit organizations; however, it soon proved to be applicable in different disciplines due to its flexibility, in that it does not require any assumptions about the functional form of the relationship between inputs and outputs, nor are any specific distributional assumptions made about inefficiency. Table 1 presents a literature review of the application of this methodology in the field of water use.

This method assumes that each DMU in the sample is defined by $m$ inputs and $s$ outputs, and that outputs increase by the same percentage as inputs, that is, constant returns to scale (CRS) are assumed. In the present research, the output-oriented DEA model has been chosen as the objective is to maximize GWS with the available inputs. The efficiency level of each DMU is calculated by solving the following linear programming model:

$$
\operatorname{Min}_{\mu} h_{0}=\sum_{i=1}^{m} v_{i} x_{i 0}
$$

Subject to:

$$
\begin{gathered}
\sum_{r=1}^{s} u_{r} y_{r 0}=1 \\
\sum_{r=1}^{s} u_{r} y_{r j}-\sum_{i=1}^{m} v_{i} x_{i j} \leq 0 j=1, \ldots n
\end{gathered}
$$









$$
u_{r}, v_{i} \geq 0 r=1, \ldots, s i=1, \ldots, m
$$

Where:

$x_{i j}$ : quantities of input $i$ consumed by the $j$-th unit

$Y_{r j}$ : observed quantities of output $r$ produced by the $j$-th unit

$o r_{r}$ : weights of the inputs

$v_{i}$ : weights of the inputs

The solution of these $n$ linear models provides the value of the weights $\left(\right.$ or $\left._{r}, v_{i}\right)$ corresponding to the inputs/outputs of each DMU that place it in the best possible position relative to the other DMUs, to which end the corresponding dual model must be solved. The efficiency scores range between 0 and 1 , such that if $h_{0}=1$ it means that no more output can be obtained using the available inputs; that is, the DMU is efficient. Values below 1 correspond to inefficient DMUs.

The CRS model is appropriate when all the DMUs operate on the same scale; if they do not, inefficiency could be a result of a DMU not operating on the optimal scale. In response to this limitation, Banker et al. (1984) introduced the assumption of variable returns to scale (VRS).

The CRS model is used to calculate the overall technical efficiency (TE) and the VRS model to calculate pure technical efficiency (PTE), while scale efficiency (SE) can be calculated as the ratio between TE and PTE. The value of SE ranges between 0 and 1, taking the maximum value when the analysed DMU is operating at the optimal scale. However, despite the flexibility of DEA when it comes to solving problems with multiple inputs and outputs, it is not without its limitations. Authors such as Herrera and Pang (2005) and Medal and Sala (2011) point out that: (1) as it is a deterministic technique, the results are sensitive to the presence of outliers; (2) it is not an appropriate technique for testing hypotheses, since it does not have statistics to estimate the error; (3) it treats any deviation from the frontier as inefficiency, although it may be due to random behaviour of variables; (4) it cannot distinguish between fully efficient DMUs, meaning it is not possible to rank DMUs by their efficiency levels.

$\mathrm{CE}$ overcomes the latter limitation, making it possible to establish a complete ranking of all the DMUs in the sample according to their level of efficiency. This method consists of calculating the efficiency score of each DMU $n$ times, using the optimal multipliers obtained by evaluating each of the DMUs. The value of each element of the CE matrix is calculated using the following expression:

$$
E_{k j}=\frac{\sum_{r=1}^{s} u_{r k} y_{r j}}{\sum_{i=1}^{m} v_{i k} x_{i j}} j=1, \ldots, n ; k=1, \ldots, n
$$

$E_{i j}$ represents the performance of $\mathrm{DMU}_{\mathrm{j}}$ using the weights obtained for $\mathrm{DMU}_{\mathrm{k}}$. The matrix elements also range between 0 and 1 , with the values on the diagonal corresponding to the standard DEA score. Thus, the $\mathrm{CE}$ value for $\mathrm{DMU}_{\mathrm{j}}$ is obtained by the following expression:

$$
C E_{j}=\frac{1}{n} \sum_{k \neq j} E_{k j} j=1, \ldots, n
$$

The variables and parameters that define Eqs. (5) and (6) have been explained above. 
In the present study, the above methodology is applied to collective irrigation institutions in CV (Spain) that have recently adopted DI. Over the last three decades, the policy of both the regional and national governments has been to promote irrigation modernization through generous subsidies (Sanchis-Ibor et al. 2016; García-Mollá et al. 2017).

\subsection{Data Sources}

Due to the small size of the irrigated farms in the $\mathrm{CV}$, most plots make use of communal irrigation, with farmers joining associations according to the source of the water used. All the evaluated DMUs are irrigation organizations whose managers have collaborated in developing the sample (Table 2).

Type A WUAs are historical irrigation systems that date back to before the 20th century and the regulation of river flows with storage reservoirs. Their water-use rights cover irrigation requirements in climatically normal seasons and additional groundwater is generally only needed in dry years. Type B WUAs are irrigated areas created by private initiatives during the 20th century and only use groundwater, mainly from private sources. Type C WUAs use the same water source as Type B, but this was topped up in the latter half of the 20th century with surface water from canals built by the State. The new irrigation districts (D) are made up of groups of organizations who use groundwater as a complement to the surface water obtained through the large canals built by the State.

The present research proposes a novel production function in terms of the variables used: no such functional relationship can be found in the existing literature. The inputs are the investments made in recent years, either with public or private funds, the area covered by DI, and water use. This last input is used to characterize the needs of the irrigators, depending on the type of crop, the area farmed, agroclimatic variables, etc. It represents the volume of water billed annually by the irrigation community; that is, for agricultural use. On the other hand, the output to be maximized in the DEA is the GWS resulting from the use of DI and the set of investments made to this end. Estimating the impact of irrigation modernization policies on actual water consumption is a highly complex task; thus, in this study, GWS is estimated as the difference between the water used by irrigation communities before and after DI implementation, with reference to the annual water supply per unit area distributed by each organization to its irrigators.

Table 3 shows the descriptive statistics for all the variables, differentiating by the different organization types analysed. The ratio of inputs/outputs to the number of DMUs in the sample is appropriate according to Põldaru and Roots (2014) and Toloo et al. (2015).

The descriptive statistics show a high degree of dispersion, regardless of the organization type under analysis. Each type includes communities of different sizes and with

Table 2 Types of irrigation organizations in the CV

\begin{tabular}{lll}
\hline & Organization type & Water source \\
\hline A & Traditional WUAs & $\begin{array}{c}\text { Surface water with occasional } \\
\text { reliance on groundwater } \\
\text { B }\end{array}$ \\
C & Private groundwater WUAs & Groundwater \\
D & WUAs for groundwater topped up with surface water & Surface water and groundwater \\
\hline
\end{tabular}


different crops. Moreover, they are located in territories with widely differing edaphoclimatic conditions and thus extremely specific needs. However, they all share certain similarities: they are all in the $\mathrm{CV}$, where there is widespread awareness of the need to generate GWS, and in recent years investments have been made and subsidies granted for this purpose. These shared characteristics mean the sample is sufficiently homogenous for the correct application of the DEA. Table 4 presents the variables that compose the production functions proposed in the empirical analysis.

These two models allow a more precise analysis of the situation. They both depend on the type of production that characterizes water consumption and are oriented at determining the resulting GWS. The first model analyses the efficiency of all the investments made, and the second specifically focuses on DI.

Table 3 Descriptive statistics by organization type

\begin{tabular}{|c|c|c|c|c|}
\hline \multirow[t]{2}{*}{ Organization type } & \multirow{2}{*}{$\begin{array}{l}\text { Investment } \\
\text { expenditure } \\
\text { Input }\end{array}$} & \multirow{2}{*}{$\begin{array}{l}\text { Water use } \\
\text { Input }\end{array}$} & \multirow{2}{*}{$\begin{array}{l}\text { Drip irrigation } \\
\text { Input }\end{array}$} & \multirow{2}{*}{$\begin{array}{l}\text { Gross water savings } \\
\text { Output }\end{array}$} \\
\hline & & & & \\
\hline Units & $(€)$ & $\left(\mathrm{m}^{3}\right)$ & (ha) & $\left(\mathrm{m}^{3}\right)$ \\
\hline \multicolumn{5}{|l|}{$\mathbf{A}$} \\
\hline Mean & $8,988,723$ & $7,787,084$ & 705 & $3,507,934$ \\
\hline St. Deviation & $10,921,430$ & $8,352,700$ & 796 & $4,098,276$ \\
\hline Min & 58,011 & 24,750 & 2 & 10,395 \\
\hline Max & $28,554,859$ & $20,886,024$ & 2,406 & $12,126,240$ \\
\hline $\mathrm{N}^{\mathrm{o}}$ DMUs & 11 & 11 & 11 & 11 \\
\hline \multicolumn{5}{|l|}{ B } \\
\hline Mean & $10,599,311$ & $4,630,606$ & 677 & $1,847,758$ \\
\hline St. Deviation & $14,278,561$ & $4,574,775$ & 699 & $1,823,039$ \\
\hline Min & 302,000 & 313,500 & 38 & 156,560 \\
\hline Max & $34,167,461$ & $11,520,000$ & 1,958 & $4,976,640$ \\
\hline $\mathrm{N}^{\circ}$ DMUs & 9 & 9 & 9 & 9 \\
\hline \multicolumn{5}{|l|}{$\mathbf{C}$} \\
\hline Mean & $10,814,643$ & $14,737,500$ & 1,919 & $7,116,180$ \\
\hline St. Deviation & $8,267,908$ & $8,223,964$ & 1,057 & $3,635,150$ \\
\hline Min & $1,257,000$ & $4,554,000$ & 498 & $2,211,120$ \\
\hline $\operatorname{Max}$ & $20,826,190$ & $24,674,400$ & 3,050 & $10,980,000$ \\
\hline $\mathrm{N}^{\circ}$ DMUs & 4 & 4 & 4 & 4 \\
\hline \multicolumn{5}{|l|}{ D } \\
\hline Mean & $6,578,139$ & $7,739,491$ & 1,285 & $3,133,260$ \\
\hline St. Deviation & $4,949,003$ & $5,356,453$ & 914 & $2,916,596$ \\
\hline Min & $1,745,601$ & $3,292,020$ & 630 & 945,000 \\
\hline Max & $13,498,469$ & $14,936,659$ & 2,593 & $7,156,680$ \\
\hline $\mathrm{N}^{\circ}$ DMUs & 4 & 4 & 4 & 4 \\
\hline \multicolumn{5}{|l|}{ Total } \\
\hline Mean & $9,422,889$ & $7,758,619$ & 952 & $3,436,245$ \\
\hline St. Deviation & $10,813,221$ & $7,295,279$ & 895 & $3,532,966$ \\
\hline Min & 58,011 & 24,750 & 2 & 10,395 \\
\hline Max & $34,167,461$ & $24,674,400$ & 3,050 & $12,126,240$ \\
\hline $\mathrm{N}^{\circ}$ DMUs & 28 & 28 & 28 & 28 \\
\hline
\end{tabular}


Table 4 Inputs/Outputs of the production functions

\begin{tabular}{lll}
\hline & Inputs & Outputs \\
\hline Model 1 & $\begin{array}{l}\text { Investment expenditure } \\
\text { Water use }\end{array}$ & Gross water savings \\
Model 2 & $\begin{array}{l}\text { Drip irrigation } \\
\text { Water use }\end{array}$ & Gross water savings \\
\hline
\end{tabular}

\section{Results and Discussion}

The efficiency of the investments made by the irrigation organizations in the sample has been calculated using CRS and VRS to determine the TE as well as the PTE and SE for each of the output-oriented models. Table 5 shows the main results obtained depending on the inputs considered.

On average, no major differences are observed in the levels of efficiency according to the model analysed, with model 2 yielding only slightly higher values. These higher values are because the investments made include works that were not directly aimed at achieving GWS. Although in Spain, as in other countries (Venot et al. 2014; Berbel et al. 2019; Sinha et al. 2019), the discourse surrounding irrigation modernization emphasizes water-use efficiency, many WUAs have made investments (taking advantage of available subsidies) aimed at reducing irrigation operating costs (irrigation ponds, pumps, electrical installations, automation), improving convenience for farmers (elimination of night-time irrigation), incorporating new resources to improve water supply guarantee, and replacing obsolete infrastructure, among other objectives. Specifically, model 2 shows an efficiency level close to $80 \%$ (TE $=0.797$ and PTE $=0.812$ ). Conversely, when analysing the investments more generally (model 1 ), this percentage decreases by more than $5 \%$ (TE $=0.759$ ) under CRS.

Returns to scale refer to changes in GWS resulting from a proportional change in all the inputs. On average, both models are close to the optimum in terms of the SE obtained ( $96.6 \%$ and $98.5 \%$, respectively); that is, GWS increases by the same proportion as the

Table 5 Efficiency levels of the models

\begin{tabular}{llll}
\hline & Model 1 & & \\
\cline { 2 - 4 } & TE & PTE & SE \\
\hline Mean & 0.759 & 0.790 & 0.966 \\
St. deviation & 0.163 & 0.176 & 0.066 \\
\% Efficient org & $7.14 \%$ & $17.86 \%$ & $7.14 \%$ \\
$\mathbf{N}^{\mathbf{o}}$ exp. drs & & & $8(28.57 \%)$ \\
$\mathbf{N}^{\mathbf{0}}$ exp. irs & & & $18(64.29 \%)$ \\
& Model 2 & & \\
Mean & TE & PTE & SE \\
St. deviation & 0.797 & 0.812 & 0.985 \\
$\%$ Efficient org & 0.164 & 0.169 & 0.043 \\
$\mathbf{N}^{\mathbf{0}}$ exp. drs & $10.71 \%$ & $14.28 \%$ & $10.71 \%$ \\
$\mathbf{N}^{\mathbf{0}}$ exp. irs & & & $1(3.35 \%)$ \\
\hline
\end{tabular}

irs increasing returns to scale, drs decreasing returns to scale, - constant returns to scale 
inputs. However, only $7.14 \%$ and $10.71 \%$ of organizations in models 1 and 2, respectively, are working at their optimal scale. Specifically, in model 2, there are 24 entities with increasing returns to scale $(85.71 \%)$, meaning that their GWS increases by more than the proportional change in resources. This indicates that efficiency improves as the size of the area converted to DI increases.

Figure 1 shows the average efficiency levels obtained by organization type, in order to detect possible differences. A better performance is observed for type C WUAs in model 1 and for type A WUAs in model 2, results that will be reinforced by the improvement needs shown in Table 6.

DEA indicates the optimal combination of input/outputs in order for a DMU to be on the efficient frontier. Table 6 shows the improvement required in each of the variables to reach the maximum efficiency level; in other words, it shows the amount by which the inputs should be reduced and the output increased.

Although there are significant differences in said amounts, a certain similarity is observed between the same organizations analysed by the two models. While type C WUAs register the best performance in terms of the results of model 1, type A WUAs achieve the best mean efficiency scores in model 2 . For types $\mathrm{B}$ and $\mathrm{D}$, we observe a distance from the frontier in terms of GWS of close to or greater than $40 \%$ in the two models. The excessive investment by type B irrigation communities is also notable: they could reduce investment expenditure by around $65 \%$ if the only goal were GWS. This can be explained by the fact that the investments made in these entities are not all aimed at achieving water savings. Even so, the efficiency values are acceptable.

The mean efficiency values conceal differences between the organizations included in each type of WUA. In line with the research objectives, CE has been applied to distinguish between efficient DMUs, establishing a ranking of all these units to facilitate their individual analysis. The resulting ranking points to possible patterns in performance (Table 7) that appear to be related to the type of irrigation organization, due to the differing water-use efficiency of each irrigation system prior to the investments being made.

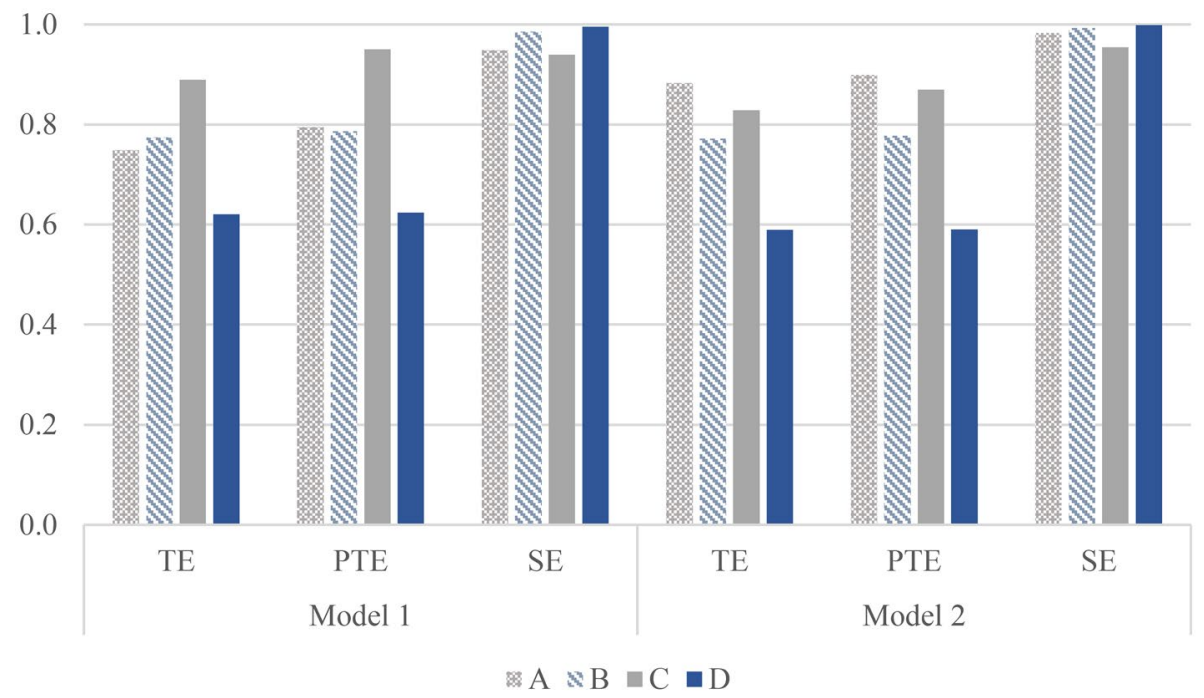

Fig. 1 Average efficiency levels by organization type 
Table 6 Improvement required in the variables to achieve maximum efficiency by organization type

\begin{tabular}{|c|c|c|c|c|}
\hline & \multicolumn{4}{|l|}{ Model 1} \\
\hline & \multicolumn{2}{|l|}{ Reduce } & \multirow{2}{*}{$\begin{array}{l}\text { Increase } \\
\text { GWS }\end{array}$} & \multirow[t]{2}{*}{ Mean PTE } \\
\hline & Investment expenditure & Water use & & \\
\hline $\mathbf{A}$ & $24.4 \%$ & $0.8 \%$ & $25.4 \%$ & 0.795 \\
\hline B & $65.4 \%$ & $0.0 \%$ & $41.6 \%$ & 0.787 \\
\hline $\mathrm{C}$ & $11.6 \%$ & $0.0 \%$ & $5.1 \%$ & 0.950 \\
\hline D & $8.6 \%$ & $0.0 \%$ & $40.4 \%$ & 0.624 \\
\hline \multirow[t]{4}{*}{ Total } & $35.6 \%$ & $0.3 \%$ & $24.1 \%$ & 0.790 \\
\hline & Model 2 & & & \\
\hline & Reduce & & Increase & Mean PTE \\
\hline & Drip irrigation & Water use & GWS & \\
\hline A & $0.0 \%$ & $0.0 \%$ & $5.0 \%$ & 0.899 \\
\hline B & $25.4 \%$ & $0.0 \%$ & $39.3 \%$ & 0.777 \\
\hline C & $16.1 \%$ & $7.6 \%$ & $14.3 \%$ & 0.870 \\
\hline D & $28.3 \%$ & $0.0 \%$ & $48.1 \%$ & 0.590 \\
\hline Total & $15.9 \%$ & $2.1 \%$ & $19.3 \%$ & 0.812 \\
\hline
\end{tabular}

The efficiency achieved by each WUA is determined by the characteristics of their organization type, as posited in the hypothesis. However, there are other factors that also have a significant influence. It can be seen from the results that some of the traditional surface water irrigation organizations show widely diverging efficiency values in terms of GWA, while more uniform performance is observed in the other three types. On the one hand, type $\mathrm{B}$ and $\mathrm{C}$ organizations show moderate or high investment efficiency in both models. This is due to their plot structure, characterized by a marked spatial dispersion of the irrigation plots. Both types correspond to areas that were originally supplied with private water and whose owners acquired water rights to wells and built pipelines to reach their farms, without having to be close to or next to boreholes or other irrigated plots. This gave rise to highly fragmented plot structures and therefore more complex water systems, with low water conveyance efficiencies. Hence, these organizations achieve a very significant improvement in water-use efficiency with the conversion to DI, and good level of efficiency in the investments aimed at GWS. The three WUAs in the Vinalopó basin (La Romana, Virgen de las Nieves, Monforte del Cid), where there is intense pressure on water resources and a predominant crop (table grape) with lower water requirements than citrus fruits, show low investment efficiency. This can be attributed to the fact that the pressure on the resource is already very high there, meaning there is little room for improvement.

On the other hand, type D WUAs are compact irrigable areas whose distribution networks were designed by technicians in the second half of the 20th century and which tend to show greater water conveyance efficiency. Furthermore, in the case of the D-type, the high price of groundwater in the local area (the most expensive in the region) prompted very efficient water even before the conversion to DI. Therefore, investments in localized irrigation do not generate as much GWS.

The dispersion seen in traditional irrigation (type A), regardless of whether other factors may play a role, is also consistent with this argument. Before modernization, a study was carried out (Marco et al. 1994) of the largest traditional irrigation systems in the region, which covered five of the type A organizations analysed in this study. Three of them border 
Table 7 Ranking of irrigation organizations

\begin{tabular}{|c|c|c|c|c|c|}
\hline \multirow[b]{2}{*}{ DMU } & \multirow[b]{2}{*}{$\begin{array}{l}\text { Organization } \\
\text { type }\end{array}$} & \multicolumn{2}{|c|}{ Model 1} & \multicolumn{2}{|c|}{ Model 2} \\
\hline & & $\mathbf{C E}$ & Ranking & $\mathbf{C E}$ & Ranking \\
\hline C.R.Vila-real & A & 0.982 & 1 & 0.986 & 1 \\
\hline C.R. Canales Bajos del Serpis & A & 0.781 & 7 & 0.925 & 2 \\
\hline C.R. Pere Jaume & A & 0.667 & 13 & 0.923 & 3 \\
\hline C.R. Nuestra Señora de la Merced & A & 0.763 & 9 & 0.844 & 4 \\
\hline C.R. Pedreguer & $\mathrm{B}$ & 0.740 & 10 & 0.801 & 5 \\
\hline C.R. Canal Cota 220 & $\mathrm{C}$ & 0.788 & 6 & 0.783 & 6 \\
\hline Agrupación de Regantes Pinella & $\mathrm{C}$ & 0.812 & 5 & 0.781 & 7 \\
\hline C.R. Pantano de María Cristina & $\mathrm{C}$ & 0.893 & 2 & 0.780 & 8 \\
\hline C.R. Castellón & A & 0.729 & 11 & 0.776 & 9 \\
\hline Cooperativa de Riegos Vall d’Uixó & $\mathrm{B}$ & 0.865 & 3 & 0.770 & 10 \\
\hline Sociedad de Riegos Unión Agrícola & $\mathrm{B}$ & 0.632 & 17 & 0.769 & 11 \\
\hline Cooperativa de Riegos Maquial & $\mathrm{B}$ & 0.608 & 18 & 0.765 & 12 \\
\hline Sociedad de Riegos La Primitiva & $\mathrm{B}$ & 0.643 & 15 & 0.764 & 13 \\
\hline Cooperativa de Riegos Pla Pinar & $\mathrm{B}$ & 0.686 & 12 & 0.762 & 14 \\
\hline C.R. Bétera & $\mathrm{C}$ & 0.816 & 4 & 0.732 & 15 \\
\hline Sindicato de Riegos de Sagunto & A & 0.516 & 23 & 0.722 & 16 \\
\hline C.R. Riego.Nuevo & A & 0.534 & 20 & 0.718 & 17 \\
\hline C.R. Torres & A & 0.517 & 22 & 0.715 & 18 \\
\hline C.R. Riego Mayor y de Abajo & A & 0.519 & 21 & 0.715 & 19 \\
\hline C.R. La Romana & $\mathrm{B}$ & 0.637 & 16 & 0.701 & 20 \\
\hline C.R. La Pila y Cap Negret & $\mathrm{A}$ & 0.481 & 24 & 0.701 & 21 \\
\hline Canal Júcar Turia - Sector 4 & $\mathrm{D}$ & 0.781 & 8 & 0.675 & 22 \\
\hline C.R. Almassora & A & 0.540 & 19 & 0.584 & 23 \\
\hline Canal Júcar Turia - Sector X & $\mathrm{D}$ & 0.648 & 14 & 0.578 & 24 \\
\hline SAT Virgen de las Nieves & $\mathrm{B}$ & 0.342 & 27 & 0.419 & 25 \\
\hline Canal Júcar Turia - Sector XI & $\mathrm{D}$ & 0.421 & 25 & 0.393 & 26 \\
\hline Canal Júcar Turia- San Rafael Benifaió & $\mathrm{D}$ & 0.375 & 26 & 0.326 & 27 \\
\hline C.R. Monforte del Cid & $\mathrm{B}$ & 0.335 & 28 & 0.318 & 28 \\
\hline
\end{tabular}

one another - CR Vila-real, CR Castellón, and CR Almassora — and present very different values in the ranking. This is consistent with the aforementioned study, which indicated that DI would not generate significant GWS in CR Castellón and CR Almassora, but would lead to an increase in irrigation costs; indeed, DI was only recommended in the case of Vila-Real. Marco et al. (1994) also analysed the case of CR Canales Bajos del Serpis and CR Sagunto, which again show disparate values in the ranking. The case of CR Canales Bajos del Serpis was highlighted as one of the few traditional irrigated lands where DI was expected to yield significant GWS. Conversely, in the case of CR Sagunto, which is much lower in the ranking, the study recommended that efficiency gains should not be the objective, but rather reduced costs and greater convenience for the irrigator.

In short, the water-use efficiency of each irrigation system prior to DI can be considered a fundamental determinant of organizations' position in the ranking, albeit not the only one. The results show discrepancies between the two rankings, except for CR Vila-real, 
which heads the ranking for both models. This is because the organizations whose DI yields GWS close to the maximum efficiency level receive additional funds that are not directed to this end. For example, CR Canales Bajos del Serpis ranks second in model 2, but drops to seventh when the volume of investments made is analysed. This pattern is repeated with others such as CR Pere Jaume or CR Pedreguer. The investment expenditure and DI are justified simply because they allow cultivation in areas where it would be hard to employ traditional irrigation with the existing resources. According to other studies, irrigation efficiency is lower in areas where crop water requirements are low (Cao et al. 2020). Conversely, the organizations that hold the top spots in the ranking, such as CR Vila-real or CR Pantano de María Cristina, are traditional organizations that had a plentiful supply of water before modernization, and have been able to significantly reduce the amount used following the conversion to DI.

As indicated above, few studies use a methodology similar to that used in this study to measure efficiency. While other studies highlight the improvement in water-use efficiency achieved by installing DI (Ali et al. 2020), they point to other factors that limit efficiency. For example, the training of farmers and technicians in the WUAs, the size of the farms or the proper management and organization of the irrigation procedures (Pereira and Marques 2017; Ali et al. 2020; Cao et al. 2020, Gautam et al. 2020). These factors could also explain the differences in efficiency between WUAs with similar characteristics in this study.

\section{Conclusions}

The CV has undergone a period of expansion of DI implementation that has brought about unprecedented technological change in the local agriculture and a large increase in the area irrigated with DI. In this study, DEA has been used to assess the efficiency of the irrigation policies adopted, analysing each WUA individually and by organization type, in order to determine whether their specific characteristics may have affected the GWS.

The results of the empirical analysis reveal that the efficiency achieved in terms of GWS is, in general, acceptable but there is still plenty of room for improvement. On average, investments focused on DI could increase GWS by $19.3 \%$ (model 1) compared to $24.1 \%$ in model 2, which accounts for all the investments made by irrigators. There are some notable differences in the results according to the different types of WUA: for private groundwater WUAs (type B) and irrigation areas developed by the State (type D), proper management of water resources could increase GWS by more than $40 \%$. This suggests that the actors involved have pursued other goals, such as making irrigation more convenient for farmers, who tend to be elderly, or guaranteeing the supply of water for their crops. This is especially the case for organizations relying on groundwater, which target a large share of the investment expenditure at infrastructure that does not increase GWS.

In addition, the use of the DEA method has made it possible not only to identify the irrigation organizations that have made improvements in terms of GWS, but also to distinguish between the levels of efficiency reached according to the type of organization. The infrastructure situation prior to modernization is a determinant of the efficiency achieved, albeit not the only one. Indeed, it was in the irrigation organizations relying on groundwater, which had less room for improvement in terms of water savings, where modernization first took place. Although the main promise of the different irrigation modernization programmes was GWS, DI was not initially installed where the potential savings were greatest, but rather where 
water resources were more expensive and the water supply was less reliable. For this reason, although GWS is the stated aim of public administrations, there is a need for a thorough evaluation of the objectives and results of the modernization programmes.

The main limitation of the empirical analysis lies in the lack of information on the specific targets of all the investments made by the irrigation organizations. Therefore, the logical continuation of this research would be to carry out a more exhaustive survey to reveal the various modernization initiatives introduced with public funds. Another important limitation is that the data on water savings are at the level of the irrigation community. Due to the complexity of the hydrological cycles, the results obtained cannot be extrapolated to the level of the water body or river basin.

Authors Contribution All authors contributed to the conception and design of the study. Material preparation, data collection and analysis were performed by M García-Mollá, R Puertas and C Sanchis-Ibor. The first draft of the manuscript was written by M García-Mollá and all authors commented on previous versions of the manuscript. All authors read and approved the final manuscript.

Funding Open Access funding provided thanks to the CRUE-CSIC agreement with Springer Nature. This study has been supported by the ADAPTAMED project ((RTI2018-101483-B-I00) and by the former IMPADAPT project (CGL2013-48424-C2-1-R) with Spanish MINECO (Ministerio de Economía y Competitividad) and European FEDER funds.

Availability of Data and Material The information has been obtained through surveys. If necessary, the database could be made available.

Code Availability Estimates have been made with Rstudio software using the deaR package.

\section{Declarations}

Ethics Approval There are no relevant waivers or approvals.

Consent to Participate Authors consent to their participation in the entire review process.

Consent for Publication Authors allow publication if the research is accepted.

Competing Interests The authors declare that they have no known competing financial interests or personal relationships that could have appeared to influence the work reported in this paper.

Open Access This article is licensed under a Creative Commons Attribution 4.0 International License, which permits use, sharing, adaptation, distribution and reproduction in any medium or format, as long as you give appropriate credit to the original author(s) and the source, provide a link to the Creative Commons licence, and indicate if changes were made. The images or other third party material in this article are included in the article's Creative Commons licence, unless indicated otherwise in a credit line to the material. If material is not included in the article's Creative Commons licence and your intended use is not permitted by statutory regulation or exceeds the permitted use, you will need to obtain permission directly from the copyright holder. To view a copy of this licence, visit http://creativecommons.org/licenses/by/4.0/.

\section{References}

Ali A, Xia C, Jia C, Faisal M (2020) Investment profitability and economic efficiency of the drip irrigation system: Evidence from Egypt. Irrig Drain 69(5):1033-1050. https://doi.org/10.1002/ird.2511

Al-Mezeini NK, Oukil A, Al-Ismaili AM (2020) Investigating the efficiency of greenhouse production in Oman: A two-stage approach based on Data Envelopment Analysis and double bootstrapping. J Clean Prod 247:119160. https://doi.org/10.1016/j.jclepro.2019.119160 
Bagchi M, Rahman S, Shunbo Y (2019) Growth in agricultural productivity and its components in Bangladeshi regions (1987-2009): An application of bootstrapped data envelopment analysis (DEA). Economies 7(2):37. https://doi.org/10.3390/economies7020037

Bai S, Kang Y, Wan S (2020) Winter wheat growth and water use under different drip irrigation regimes in the North China Plain Winter wheat growth and water use under different drip irrigation regimes in the North China Plain. Irrig Sci 38:321-335. https://doi.org/10.1007/s00271-020-00673-4

Banker RD, Charnes A, Cooper WW (1984) Some models for estimating technical and scale inefficiencies in data envelopment analysis. Manag Sci 30:1078-1092. https://doi.org/10.1287/mnsc.30.9. 1078

Berbel J, Expósito A, Gutiérrez-Martín C, Mateos L (2019) Effects of the irrigation modernization in Spain 2002-2015. Water Resour Manag 33:1835-1849. https://doi.org/10.1007/s11269-019-02215-w

Berbel J, Gutiérrez-Martín C, Rodríguez-Díaz JA, Camacho E, Montesinos P (2015) Literature review on rebound effect of water saving measures and analysis of a Spanish case study. Water Resour Manag 293:663-678. https://doi.org/10.1007/s11269-014-0839-0

Boelens R, Perreault T, Vos J (2018) Water justice. Cambridge University Press

Cao X, Xiao J, Wu M, Zeng W, Huang X (2021) Agricultural water use efficiency and driving force assessment to improve regional productivity and effectiveness. Water Resour Manag 35:25192535. https://doi.org/10.1007/s11269-021-02845-z

Cao Y, Zhang W, Ren J (2020) Efficiency analysis of the input for water-saving agriculture in China. Water 12(1):207. https://doi.org/10.3390/w12010207

Charnes A, Cooper W, Rhodes E (1978) Measuring the efficiency of decision making units. Eur J Oper Res 2:429-444. https://doi.org/10.1016/0377-2217(78)90138-8

Cinaroglu S (2021) Oncology services efficiency in the age of pandemic: A jackknife and bootstrap sensitivity analysis for robustness check of DEA scores. J Cancer Policy 27:100262. https://doi.org/10. 1016/j.jcpo.2020.100262

De los Reyes MLF, Schultz B (2018) Modernization of national irrigation systems in the Philippines: Linking design, operation and water supply. Irrig Drain 68(1):59-66. https://doi.org/10.1002/ird.2260

FAO (2017) Water for sustainable food and agriculture: A report produced for the G20 presidency of Germany. Food and Agriculture Organization of the United Nations, Rome. http://www.fao.org/3/ a-i7959e.pdf

Gautam TK, Paudel KP, Guidry KM (2020) An evaluation of irrigation water use efficiency in crop production using a data envelopment analysis approach: A case of Louisiana, USA. Water 12(11):3193. https://doi.org/10.3390/w12113193

Geng Q, Ren Q, Nolan RH, Wu P, Yu Q (2019) Assessing China's agricultural water use efficiency in a green-blue water perspective: A study based on data envelopment analysis. Ecol Indic 96:329-335. https://doi.org/10.1016/j.ecolind.2018.09.011

Geng X (2020) On the regional differences in agricultural water use efficiency in China and their convergence. Int J Des Nat Ecodynamics 15(2):189-196. https://doi.org/10.18280/ijdne.150208

Golany B, Roll Y (1989) An application procedure for DEA. Omega 17(3):237-250. https://doi.org/10. 1016/0305-0483(89)90029-7

García-Mollá M, Sanchis-Ibor C, Avellà L (2017) La modernización de regadíos en las entidades de riego valencianas. Efectos en el uso y costes del agua. In: Berbel J, Gutiérrez-Martín C, (ed) Efectos de la modernización de regadíos en España. Cajamar Caja Rural, Almería

Grafton RQ, Williams J, Perry CJ, Molle F, Ringler C, Steduto P, Udall B, Wheeler SA, Wang Y, Garrick D (2018) The paradox of irrigation efficiency. Science 361:748-750. https://doi.org/10. 1126/science.aat9314

Guo Y, Yu Y, Ren H, Xu L (2020) Scenario-based DEA assessment of energy-saving technological combinations in aluminum industry. J Clean Prod 260:121010. https://doi.org/10.1016/j.jclepro.2020.121010

GVA (2020) Informe del Sector Agrari Valencià, València: Generalitat Valenciana. Available online: http:// www.agroambient.gva.es/va/informes-del-sector-agrario-valenciano (accessed on 31 Jan 2021)

Hafsal K, Suvvari A, Durai SRS (2020) Efficiency of Indian banks with non-performing assets: evidence from two-stage network DEA. Future Bus J 6:26. https://doi.org/10.1186/s43093-020-00030-z

Herrera S, Pang G (2005) Efficiency of public spending in developing countries: An efficiency frontier approach Vol. 1, 2 \& 3. Policy Res Work Pap. https://doi.org/10.1596/1813-9450-3645

Huang D, Shen Z, Sun C, Li G (2021) Shifting from production-based to consumption-based nexus governance: evidence from an input-output analysis of the local water-energy-food nexus. Water Resour Manag 35:1673-1688. https://doi.org/10.1007/s11269-021-02797-4

Imran MA, Ali A, Ashfaq M, Hassan S, Culas R, Ma C (2019) Impact of climate smart agriculture (CSA) through sustainable irrigation management on Resource use efficiency: A sustainable 
production alternative for cotton. Land Use Pol 88:104113. https://doi.org/10.1016/j.landusepol. 2019.104113

INE (2011) Censo Agrario 2009. Instituto Nacional de Estadística (Statistics National Institute): Madrid, Spain. Available online: http://www.pegv.gva.es/es/temas/agriculturaganaderiaselviculturacazapesc ayacuicultura/censoagrario/censoagrario2009 (accessed on 1 July 2020)

Khadra R, Sagardoy JA (2019) Irrigation governance challenges in the Mediterranean Region: Learning from experiences and promoting sustainable performance. Springer, New York

Li N, Jiang Y, Mu H, Yu Z (2018) Efficiency evaluation and improvement potential for the Chinese agricultural sector at the provincial level based on data envelopment analysis (DEA). Energy 164:1145-1160. https://doi.org/10.1016/j.energy.2018.08.150

Lombardi GV, Stefani G, Paci A, Becagli C, Miliacca M, Gastaldi M, Giannetti BF, Almeida CMVB (2019) The sustainability of the Italian water sector: An empirical analysis by DEA. J Clean Prod 227:1035-1043. https://doi.org/10.1016/j.jclepro.2019.04.283

MAPA (2020) Encuesta sobre Superficies y Rendimientos de Cultivos (ESYRCE). Madrid: Ministerios de Agricultura, Pesca y Alimentación. Available online: https://www.mapa.gob.es/es/estadistica/ temas/estadisticasagrarias/agricultura/esyrce. Accessed 6 Apr 2021

Marco JB, Mateu J, Romero J (1994) Regadíos históricos valencianos: Propuestas de rehabilitación. Conselleria d'Agricultura i Pesca, Servei d'Estudis Agraris i Comunitaris, Valencia

Martinho VJPD (2020) Efficient water management: An analysis for the agricultural sector. Water Policy 22(3):396-416. https://doi.org/10.2166/wp.2020.191

Medal A, Sala R (2011) Efficiency analysis in the Spanish Port System: Framework, evolution and perspectives. Ed. Fundación Valencia Port. Valencia

Molle F, Sanchis-Ibor C, Avella L (eds) (2019) Irrigation in the Mediterranean: Technologies Institutions and Policies. Springer, Cham (Switzerland)

Nair S, Johnson J, Wang C (2013) Efficiency of irrigation water use: A review from the perspectives of multiple disciplines. Agron J 105(2):351-363. https://doi.org/10.2134/agronj2012.0421

Narayanamoorthy A, Devika N, Suresh R, Sujitha KS (2020) Efficiency and viability of drip method of irrigation in groundnut cultivation: an empirical analysis from South India. Water Policy 22(6):1109-1125. https://doi.org/10.2166/wp.2020.257

Nazari B, Liaghat A, Akbari MR, Keshavarz M (2018) Irrigation water management in Iran: Implications for water use efficiency improvement. Agric Water Manag 208:7-18. https://doi.org/10. 1016/j.agwat.2018.06.003

Pereira H, Marques RC (2017) An analytical review of irrigation efficiency measured using deterministic and stochastic models. Agric Water Manag 184:28-35. https://doi.org/10.1016/j.agwat.2016.12.019

Perry C, Steduto P (2017) Does improved irrigation technology save water? A review of the evidence. Cairo: Food and Agriculture Organization of the United Nations

Poblador N, Sanchis-Ibor C, Kuper M (2021) The landing of parachuted technology: Appropriation of centralised drip irrigation systems by irrigation communities in the region of Valencia (Spain). Water Altern 14(1):228-247

Põldaru R, Roots J (2014) A PCA-DEA approach to measure the quality of life in Estonian counties. Socio-Econ Plan Sci 48(1):65-73. https://doi.org/10.1016/j.seps.2013.10.001

Rezaee MJ, Yousefi S, Eshkevari M, Valipour M, Saberi M (2020) Risk analysis of health, safety and environment in chemical industry integrating linguistic FMEA, fuzzy inference system and fuzzy DEA. Stoch Environ Res Risk Assess 34:201-218. https://doi.org/10.1007/s00477-019-01754-3

Sanchis-Ibor C, García-Mollá M, Avellà-Reus L (2016) Las políticas de implantación del riego localizado. Efectos en las entidades de riego de la Comunidad Valenciana. Boletín de la Asociación de Geógrafos Españoles 72:9-36. https://doi.org/10.21138/bage.2330

Sinha R, Gilmont M, Hope R, Dadson S (2019) Understanding the effectiveness of investments in irrigation system modernization: evidence from Madhya Pradesh, India. Int J Water Resour Dev 35(5):847-870. https://doi.org/10.1080/07900627.2018.1480357

Song M, Wang R, Zeng X (2018) Water resources utilization efficiency and influence factors under environmental restrictions. J Clean Prod 184:611-621. https://doi.org/10.1016/j.jclepro.2018.02.259

Sukmana R, Ajija SR, Salama SCU, Ahmad Hudaifah A (2020) Financial performance of rural banks in Indonesia: A two-stage DEA approach. Heliyon 6(7):e04390. https://doi.org/10.1016/j.heliyon. 2020.e04390

Toloo M, Barat M, Masoumzadeh A (2015) Selective measures in data envelopment analysis. Ann Oper Res 226(1):623-642. https://doi.org/10.1007/s10479-014-1714-3

Tsakmakis ID, Zoidou M, Gikas GD, Sylaios GK (2018) Impact of irrigation technologies and strategies on cotton water footprint using AquaCrop and CROPWAT models. Environ Process 5:181-199. https:// doi.org/10.1007/s40710-018-0289-4 
United Nations (2020) The United Nations world water development report 2020: water and climate change. UNESCO World Water Assessment Programme

Venot JP, Zwarteveen M, Kuper M, Boesveld H, Bossenbroek L, van der Kooij S, Wanvoeke J, Benouniche M, Errahj M, De Fraiture C, Verma S (2014) Beyond the promises of technology: A review of the discourses and actors who make drip irrigation. Irrig Drain 63(2):186-194. https://doi.org/10.1002/ ird.1839

Venot JP, Kuper M, Zwarteveen M (2017) Drip irrigation for agriculture: untold stories of efficiency, innovation and development. Earthscan from Routledge, Abingdon

Volschenk T (2020) Water use and irrigation management of pomegranate trees - A review. Agric Water Manag 241:106375. https://doi.org/10.1016/j.agwat.2020.106375

Wang F, Yu C, Xiong L, Chang Y (2019) How can agricultural water use efficiency be promoted in China? A spatial-temporal analysis. Resour Conserv Recy 145:411-418. https://doi.org/10.1016/j.resconrec. 2019.03.017

Wang G, Lin N, Zhou X, Li Z, Deng X (2018) Three-stage data envelopment analysis of agricultural water use efficiency: A case study of the Heihe River Basin. Sustainability 10(2):568. https://doi.org/10. 3390/su10020568

Wang Y, Li S, Qin S, Guo H, Yang D, Lam HM (2020) How can drip irrigation save water and reduce evapotranspiration compared to border irrigation in arid regions in northwest China. Agric Water Manag 239:106256. https://doi.org/10.1016/j.agwat.2020.106256

World Bank (2019) Irrigation in Turkey to be modernized with World Bank financing. Available at http:// www.worldbank.org/en/news/pressrelease/2019/01/22/irrigation-in-turkey-to-be-modernized-withworldbank-financing. Accessed 26 Mar 2021

Yin P, Chu J, Wu J, Ding J, Yang M, Wang Y (2020) A DEA-based two-stage network approach for hotel performance analysis: An internal cooperation perspective. Omega 93:102035. https://doi.org/10. 1016/j.omega.2019.02.004

Yu L, Zhao X, Gao X, Siddique KHM (2020) Improving/maintaining water-use efficiency and yield of wheat by deficit irrigation: A global meta-analysis. Agric Water Manag 228:105906. https://doi.org/10. 1016/j.agwat.2019.105906

Publisher's Note Springer Nature remains neutral with regard to jurisdictional claims in published maps and institutional affiliations. 